\title{
Characterization of three new serous epithelial ovarian cancer cell
} lines

\author{
Véronique Ouellet ${ }^{\dagger 1}$, Magdalena Zietarska ${ }^{\dagger 1}$, Lise Portelance ${ }^{1}$, \\ Julie Lafontaine ${ }^{1}$, Jason Madore ${ }^{1}$, Marie-Line Puiffe ${ }^{1}$, Suzanna L Arcand ${ }^{2}$, \\ Zhen Shen², Josée Hébert ${ }^{3,4}$, Patricia N Toninn ${ }^{2,5,6}$, Diane M Provencher ${ }^{1,4,7}$ \\ and Anne-Marie Mes-Masson*1,4
}

\begin{abstract}
Address: ${ }^{1}$ Centre de recherche du Centre hospitalier de l'Université de Montréal (CHUM)/Institut du cancer de Montréal, Montreal, Canada, ${ }^{2}$ The Research Institute of McGill University Health Centre, Montreal, Canada, ${ }^{3}$ Leukemia Cell Bank of Quebec and Division of Hematology, Maisonneuve-Rosemont Hospital, Montreal, Quebec, Canada, ${ }^{4}$ Department of Medicine, Université de Montréal, Montreal, Quebec, Canada, ${ }^{5}$ Department of Human Genetics, McGill University, Montreal, Canada, ${ }^{6}$ Department of Medicine, McGill University, Montreal, Canada and ${ }^{7}$ Department of Obstetrics and Gynecology, Division of Gynecologic Oncology, Université de Montréal, Montreal, Canada

Email: Véronique Ouellet - ouelletv@yahoo.ca; Magdalena Zietarska - bmagda@yahoo.com; Lise Portelance - lise.portelance@sympatico.ca; Julie Lafontaine - lafontaine_julie@hotmail.com; Jason Madore - jason.madore@gmail.com; Marie-Line Puiffe - marielinepuiffe@gmail.com; Suzanna L Arcand - suzanna.arcand@mail.mcgill.ca; Zhen Shen - zhen.shen@mail.mcgill.ca; Josée Hébert - jhebert.hmr@ssss.gouv.qc.ca; Patricia N Tonin - patricia.tonin@mcgill.ca; Diane M Provencher - diane.provencher.chum@ssss.gouv.qc.ca; Anne-Marie Mes-Masson* - annemarie.mes-masson@umontreal.ca

* Corresponding author †Equal contributors
\end{abstract}

Published: 28 May 2008

BMC Cancer 2008, 8:152 doi:10.1186/147|-2407-8-152

This article is available from: http://www.biomedcentral.com/I47/-2407/8/I52

(C) 2008 Ouellet et al; licensee BioMed Central Ltd.

This is an Open Access article distributed under the terms of the Creative Commons Attribution License (http://creativecommons.org/licenses/by/2.0), which permits unrestricted use, distribution, and reproduction in any medium, provided the original work is properly cited.

\begin{abstract}
Background: Cell lines constitute a powerful model to study cancer, and here we describe three new epithelial ovarian cancer (EOC) cell lines derived from poorly differentiated serous solid tumors (TOV-1946, and TOV-2223G), as well as the matched ascites for one case (OV-1946).

Methods: In addition to growth parameters, the cell lines were characterized for anchorage independent growth, migration and invasion potential, ability to form spheroids and xenografts in SCID mice.

Results: While all cell lines were capable of anchorage independent growth, only the TOV-1946 and OV-1946 cell lines were able to form spheroid and produce tumors. Profiling of keratins, p53 and Her2 protein expression was assessed by immunohistochemistry and western blot analyses. Somatic TP53 mutations were found in all cell lines, with TOV-1946 and OV-1946 harboring the same mutation, and none harbored the commonly observed somatic mutations in BRAF, KRAS or germline BRCAI/2 mutations found to recur in the French Canadian population. Conventional cytogenetics and spectral karyotype (SKY) analyses revealed complex karyotypes often observed in ovarian disease.
\end{abstract}

Conclusion: This is the first report of the establishment of matched EOC cell lines derived from both solid tumor and ascites of the same patient. 


\section{Background}

Epithelial ovarian cancer (EOC) is often described as the silent killer or the disease that whispers mainly due to absence of symptoms. This combined with the lack of specific/sensitive markers and/or techniques of screening leads to the diagnosis at late stages of the disease in more than $70 \%$ of patients. Unfortunately, the five year survival rate at this point of the disease is less than 30\% [1]. Although EOC is not the most prevalent of cancers, it accounts for the highest number of deaths from a gynecologic malignancy.

EOC is a complex disease stratified according to histopathological and morphological criteria. The majority of EOCs are thought to arise from the ovarian surface epithelium (OSE) that is derived from the coelomic epithelium. OSE is composed of multipotent cells that can differentiate and give rise to tumors of different histopathology types $[1,2]$. The latter are defined by the International Federation of Gynecology and Obstetrics (FIGO) [3] and represent serous, endometrioid, mucinous, clear cell, de Brenner, mixed and undifferentiated subtypes. Serous type tumors are the most common subtype of EOC identified in more than $50 \%$ of cases. EOC tumors are graded according to the degree of differentiation of tumor cells which can vary from well (grade 1), moderately (grade 2) or poorly (grade 3 ) differentiated cells. Finally, EOC tumors are also classified according to the spread of the disease varying from stage I when tumors are confined to the ovaries to stage IV when distant metastases are observed.

Over the past years several laboratories, including ours [4], have established and characterized cell lines derived from EOC tumors. However, the majority of these EOC cell lines were established from patients ascites [4-29] and only few were derived from solid tumors [4,12,30-37]. Moreover, EOC cell lines have rarely been derived from chemotherapy-naive patients while others were established following viral transformation (SV40 Large T antigen) (such as NMSO cell line) [38,39] or xenograft passage in immunocompromised mice (such as the HEY, HO-8910PM, and AMOC-2 cell lines) [10,40,41]. In addition, few cell lines derived from serous EOC tumors are available even though this subtype represents the most frequently occurring histopathology subtype (such as the TOV-81D, FU-OV-1, and HOC1-7 cell lines) $[4,10,11,33,35]$.

In this study, we describe three new serous EOC cell lines that were derived in our laboratory from either solid tumors or ascites of two chemotherapy-naïve patients. This is the first report characterizing cell lines derived from both solid tumor and ascites of the same patient. Moreover, the molecular and growth characteristics of the three cell lines present some unique features thereby providing the research community with new tools in the study of different aspects of serous EOC.

\section{Methods \\ Sample and Patient data}

Tumor samples were collected and banked following surgeries performed within the Division of Gynecologic Oncology at the Centre hospitalier de l'Universite de Montréal (Hôpital Notre-Dame). The study was approved by the CHUM institutional ethics committee and written consent was obtained from patients prior to sample collection. Stage was determined at the time of surgery. Histopathology and tumor grade were assigned by a pathologist according to the International Federation of Gynecology and Obstetrics (FIGO) criteria [3].

\section{Establishment of the cell lines and culture conditions}

All primary cultures and cell lines were cultured in OSE medium (Wisent, Qc, Canada) supplemented with $10 \%$ fetal bovine serum (FBS), $2.5 \mu \mathrm{g} / \mathrm{ml}$ amphotericin B and $50 \mu \mathrm{g} / \mathrm{ml}$ gentamicin. Cells were incubated in $5 \% \mathrm{CO}_{2}$ and $5 \% \mathrm{O}_{2}$.

The TOV-1946 cell line was established using the previously described scrape method on tumor tissue from patient $1946[42,43]$. Briefly, tumor tissue was gently scraped into a $100 \mathrm{~mm}$ petri dish containing supplemented OSE medium. TOV-1946 cells were maintained in the same petri dish for the first 40 days and medium was replaced weekly. After 40 days, $80 \%$ confluence was attained and TOV-1946 cells were divided into two petri dishes. They were then divided in a proportion of 2:3 once a week for the first 15 passages and 1:2 twice a week thereafter until passage 70. Subsequently, cells were maintained and divided in a proportion of 1:5 twice a week.

The OV-1946 cell line was established from a mass of cells from the ascites of patient 1946 . The mass was macro-dissected into small pieces, which were kept in a $100 \mathrm{~mm}$ petri dish for 27 days at which point adherent cells reached $80 \%$ confluence. Pieces of tissue were then discarded. Cells were divided in a proportion of 2:3 every week for the first 15 passages and then 1:2 twice a week until passage 70 . Cells were then maintained and divided in a proportion of 1:5 twice a week.

The TOV-2223 cell line was established from patient 2223 tumor tissue using the collagenase method. Briefly, tumor tissue was macro-dissected onto a $100 \mathrm{~mm}$ petri dish containing serum free OSE medium supplemented with 1000 U of collagenase (Sigma-Aldrich, ON, Canada). After 3-4 hours at $37^{\circ} \mathrm{C}$, cells were resuspended into $8 \mathrm{ml}$ of medium and the remaining tumor tissue pieces were discarded. The medium containing cells was then divided 
into four $60 \mathrm{~mm}$ petri dishes and 10\% FBS was added. Cells were divided 1:2 once a week until passage 19 and then twice a week until passage 70 . Subsequently, cells were maintained and divided in a proportion of 1:3 twice a week.

\section{Antibodies}

For immunohistochemistry and western blot analyses, the following antibodies were used: beta actin AC-15 (ab6276 from Abcam inc. MA, USA), p53 (D0-1) (sc-126 from Santa Cruz Biotechnology, CA, USA), anti-c-ErbB2/c-Neu (OP15, Calbiochem, ON, Canada), Keratin 19 Ab-1 (Ms198-P0, Lab Vision Corp., CA, USA), Keratin 7 Ab-2 (MS-1352-P0) and Keratin 8 Ab-4 (MS-997-P0, both from NeoMarker, Medicorp, Qc, Canada).

\section{Immunohistochemistry}

Formalin fixed paraffin embedded tumors were sectioned at $4 \mu \mathrm{m}$ and the slides were stained using the immunoperoxidase method. Briefly, tissue sections were heated at $60^{\circ} \mathrm{C}$ for 30 minutes, deparaffinized in toluene and rehydrated in an ethanol gradient. Slides were submerged in boiling citrate buffer $(0.01 \mathrm{M}$ citric acid adjusted to $\mathrm{pH}$ 6.0) and microwaved for 10 min to unmask antigens. A $3 \% \mathrm{H}_{2} \mathrm{O}_{2}$ treatment was used to eliminate endogenous peroxidase activity. The sections were blocked with a protein blocking serum-free reagent (DakoCytomation Inc., ON, Canada) and incubated with different antibodies for $60 \mathrm{~min}$ at room temperature.

The optimal concentration for each primary antibody was determined by serial dilutions. Tissues were incubated with either a secondary biotinylated antibody (DakoCytomation Inc., ON, Canada) or a rabbit anti-goat biotinconjugated antibody (1:300) (sc-2774, Santa Cruz Biotechnology, CA, USA) for 20 min followed by incubation with a streptavidin-peroxidase complex (DakoCytomation Inc., On, Canada) for $20 \mathrm{~min}$ at room temperature. Reaction products were developed using diaminobenzidine containing $0.3 \% \mathrm{H}_{2} \mathrm{O}_{2}$ as a peroxidase substrate. Nuclei were counterstained with hematoxylin and all sections were observed by light microscopy at $400 \times$ magnification. Substitution of the primary antibody with phosphate buffered saline served as a negative control.

\section{Growth rate}

Growth rates were assessed as previously described [4]. On day $0,1 \times 10^{5}$ cells were seeded onto $60 \mathrm{~mm}$ petri dishes. On day 1, 3, 5, 7, 9, 11 and 13 the cells were trypsinized, resuspended in medium and counted using a hemacytometer. Each experiment was performed in triplicate for each harvest and repeated once. Saturation density was defined as the mean maximum number of cells at confluence counted from two independent experiments performed with triplicates and the doubling time was cal- culated according to the slope of the linear portion of the growth curve.

\section{Anchorage independent growth in soft agarose and three- dimensional culture}

Cell lines were assayed for their ability to grow in anchorage independent conditions by culturing $1 \times 10^{4}$ cells in agarose $(0.33 \mathrm{~g} / 100 \mathrm{ml}$ OSE complete medium for the upper layer and $0.66 \mathrm{~g} / 100 \mathrm{ml}$ OSE complete medium for the base layer) [43]. Cells were cultured in soft agar for three weeks, colonies were photographed and these were used for counting. Two independent experiments performed in duplicate.

Cell lines were tested for their ability to form three-dimensional aggregates or spheroids as previously described [44,45]. Briefly, 4000 cells were suspended in $15 \mu \mathrm{l}$ of OSE complete medium. The droplets of medium containing cells are then placed on the cover of non-coated plastic tissue culture plate. The cover is placed on a dish containing $10 \mathrm{ml}$ of PBS to prevent dehydration of the droplets. The ability to form spheroids was assessed after four days.

\section{Low serum growth}

Tumor cell growth in low serum conditions was assessed by plating cells in six well plates in OSE medium supplemented of 1\% FBS, $2.5 \mu \mathrm{g} / \mathrm{ml}$ amphotericin B and $50 \mu \mathrm{g} /$ $\mathrm{ml}$ gentamicin and cultured for 21 days. The medium was changed every seven days. The experiments were performed in duplicate.

\section{Wound-healing assay}

Migration potential was evaluated using the scratch assay method as previously described [46-48]. Briefly, cells were plated onto a 12 well dish and once the cell confluence reached about 90\% wounds were created using a $200 \mu \mathrm{l}$ plastic tip. In order to evaluate cell migration into the wound, cells were methanol fixed and treated with Giemsa Stain (Sigma-Aldrich Inc., MO, USA) at 0, 8, 24 and 48 hours after creating the wound. The experiments were performed twice in triplicate.

\section{In vitro invasion assay}

Cellular invasion was assayed by the ability of cells to invade a synthetic basement membrane (Matrigel, Becton-Dickenson, NJ, USA) using Boyden chambers. Polycarbonate membranes ( $8 \mu \mathrm{m}$ pore size) of the upper compartment of transwell culture chambers were coated with $0.4 \mu \mathrm{g} / \mathrm{ml}$ Matrigel. Ovarian cancer cells were trypsinized and resuspended in OSE medium supplemented with $1 \%$ FBS. The cell suspension $\left(20 \times 10^{3}\right.$ cells/ well) was placed in the upper compartment of the Boyden chamber, and the lower compartment was filled with OSE medium with $5 \%$ FBS. Cells were incubated at $37^{\circ} \mathrm{C}$ for 24 hours. Following incubation, membranes were metha- 
nol fixed and stained with Giemsa Stain (Sigma-Aldrich Inc., MO, USA). Non-invading cells were removed with a cotton swab, while invading cells on the underside of the membrane were counted using an inverted microscope. The experiments were performed in duplicate.

\section{In vivo growth in SCID mice}

The tumorigenic potential of cell lines was assessed based on their ability to form tumors in 45 day-old female SCID mice at subcutaneous (s.c.) left gluteal or intraperitoneal (i.p.) injection sites. Each mouse was injected with $5 \times 10^{6}$ cells suspended in phosphate buffered saline (PBS). The animals were housed under sterile conditions in a laminar flow environment with ad-lib access to food and water. Tumor formation was assessed over 180 days. Animals were sacrificed before neoplastic masses reached limit points established by the Institutional Committee on Animal Protection (CIPA) according to the Canadian Council on Animal Care.

\section{Mutation analyses}

TP53 mutations were detected by single-strand conformation polymorphism (SSCP) analysis of cell line DNA. Polymerase chain reaction (PCR) was used to amplify exons 5-9 of TP53 as previously described [49]. Mutations were detected as band shift relative to the wild-type pattern, and confirmed by sequence analysis (McGill University and Genome Quebec Innovation Centre, Montreal, Quebec, Canada). If negative by the SSCP assay, samples were sequenced for exons 2-11 (translated region), as previously described [50]. KRAS was investigated by sequencing genomic regions corresponding to codons 12 and 13 as previously described [51]. Microsatellite instability (MSI) was established as previously described [4].

BRAF exons 11 and 15 were analyzed by SSCP analysis. PCR was performed in a $12.5 \mu \mathrm{l}$ volume containing 200 ng of genomic DNA; $1.25 \mu \mathrm{Ci}$ of [35S]dATP (PerkinElmer, ON, Canada); $1 \times$ PCR buffer (Invitrogen, ON, Canada); $2.5 \mathrm{nmol}$ each dCTP, dGTP and dTTP; $0.3 \mathrm{nmol}$ dATP; $1.5 \mathrm{mM} \mathrm{MgCl} 2 ; 15 \mathrm{pmol}$ of each primer [52]; and 0.5 U of Taq DNA polymerase (Invitrogen, ON, Canada). The PCR conditions were $3 \mathrm{~min}$ at $95^{\circ} \mathrm{C}, 35$ cycles of $94^{\circ} \mathrm{C}$ for $30 \mathrm{sec}, 55^{\circ} \mathrm{C}$ for $30 \mathrm{sec}$ and $72^{\circ} \mathrm{C}$ for $30 \mathrm{sec}$. The reaction products were diluted 2:3 with stop buffer $(90 \%$ formamide, $10 \mathrm{mM}$ EDTA, $10 \%$ bromophenol blue and $10 \%$ xylene cyanol) and heated at $95^{\circ} \mathrm{C}$ for 10 min before loading on a $0.5 \times$ MDE (Mandel Scientific, ON, Canada) non-denaturing gel. The products were electrophoresed at $25 \mathrm{~W}$ at $4{ }^{\circ} \mathrm{C}$ for $6 \mathrm{~h}$. Gels were dried at $80^{\circ} \mathrm{C}$ and autoradiographed at room temperature for 2-3 days on Kodak Biomax MR film (Perkin-Elmer, ON, Canada). Mutations were detected as band shift relative to the wild-type pat- tern, and confirmed by sequence analysis (McGill University and Genome Quebec Innovation Centre).

The common French Canadian founder mutations $4446 \mathrm{C}>\mathrm{T}$ and 2953delGTAinsC in BRCA1 and 8765delAG, 6085G $>\mathrm{T}$ and 3398delAAAAG in BRCA2 were investigated in DNA from patient matched peripheral blood lymphocytes as described $[53,54]$.

\section{Conventional cytogenetics and Spectral Karyotyping (SKY) of the cell lines}

Metaphase preparation and cytogenetic analyses with a trypsin-Giemsa banding technique of the TOV-2223, TOV-1946 and OV-1946 ovarian cancer cell lines were performed according to standard cytogenetic procedures. Clonal chromosomal abnormalities and GTG-banded karyotypes were described according to the International System for Human Cytogenetic Nomenclature [55]. Metaphase cells from the same culture passage were used for standard and spectral karyotyping of each ovarian cancer cell line. Slide pretreatment, hybridization with the SkyPaint ${ }^{\mathrm{TM}}$ human probes and detection were performed with the protocol provided by Applied Spectral Imaging (ASI) [56] with minor modifications. Spectral images were acquired with a SpectraCube $e^{\circledast}$ system (ASI) mounted on a Zeiss Axioplan II microscope and analyzed using the SkyView version 1.6.1 software (ASI).

\section{Results}

\section{Primary culture, cell line and tumor tissue phenotype}

Cell lines were derived from both solid tumors (TOV1946 and TOV-2223G) and ascites (OV-1946) of two chemotherapy naive patients. Patients 1946 and 2223 from which the cell lines were derived both presented poorly differentiated (grade 3 ) serous papillary cystadenocarcinoma at stage IIIC. Based on residual tumor present following surgery, both patients were considered to be suboptimaly debulked. Patient 2223 received a palliative treatment only and survived for 18 months while patient 1946 died from post-operative complications. Patient 1946 did not have any known familial history of cancer. However, two sisters of patient 2223 were diagnosed with ovarian cancer ( 70 and 80 years old) and numerous colon cancers were diagnosed within the family. Clinical data for both patients are summarized in Table 1 .

At initial passage all three cell lines appeared more (TOV1946 and TOV-2223) or less (OV-1946) heterogenous with populations of cells with obvious fibroblastic contaminants (Figure 1A,C,E). With subsequent passages a selection toward a more homogenous population of cells occurred and cell lines presented a cobblestone morphology characteristic of epithelial cells (Figure 1B,D,F). 
Table I: Patient clinical data

\begin{tabular}{lcc}
\hline & & Patient \\
\cline { 2 - 3 } Clinical Parameter & 1946 & 2223 \\
\hline Age at diagnosis & 75 & 89 \\
Tumor type & cystadenocarcinoma & cystadenocarcinoma \\
Histopathology sub-type & serous papillary & serous papillary \\
Tumor grade & G3 & G3 \\
Disease stage & IIIC & IIIC \\
Ascitis at surgery & Yes & yes \\
Surgical debulking & Sub-optimal & Sub-optimal \\
Progression & N/A & yes \\
Death & yes* & yes \\
Cause of death & gastric hemorrhage & disease progression \\
Follow up (months) & 0.5 & Megace (palliative care only) \\
Treatment & N/A & \\
\hline
\end{tabular}

$\mathrm{N} / \mathrm{A}=$ not applicable

*patient died from post-operative complication

Hematoxylin-Eosin stained tumor tissue sections of patient 1946 and 2223 (Figure $1 \mathrm{G}$ and $1 \mathrm{H}$, respectively) presented typical poorly differentiated tumor masses. While all cell lines exhibited similar cobblestone morphologies typical of epithelial cells, the TOV-2223 cells are larger than the TOV-1946 and OV-1946 cells (Figure $1 \mathrm{~B}, \mathrm{D}, \mathrm{F})$. This reflects morphological differences in the corresponding tumor tissues where cells in the TOV-2223 tumors were larger than those observed in the 1946 tumor (Figure 1G,H).

One of the hallmarks of cancer cells is their ability to grow in the absence of exogenous growth factors, which can be verified by culturing cancer cells in low serum conditions. All cell lines were able to grow in a medium containing only $1 \%$ of FBS. In general however, growth rates were slower in low serum conditions than those observed in a typical 10\% FBS environments (data not shown).

\section{Solid tumor and cell line expression of keratins, TP53 and HER2}

In order to further establish the epithelial characteristics of our cell lines keratin expression was assessed. Both TOV-1946 and OV-1946 cell lines expressed Krt7 and hence mirror keratin expression observed in vivo in the original tumor (Figure 2A and 2I). However, the TOV1946 cell line expressed a much higher level of this keratin when compared to its ascites counterpart (Figure 2I). As reflected by immunohistochemistry and western-blot analyses, although TOV-2223 tumor tissue expressed Krt7, the corresponding cell line seems to have lost the capacity to express this particular keratin (Figure 2E and 2I). The epithelial characteristics of the cell lines were also verified by the expression of Krt18 and Krt8, which are also markers of epithelial cells. The expression of these keratins was observed only in the TOV-2223 cell line (Fig- ure 2I). The gastro-intestinal tract tumor marker Krt20 was absent in both tumor tissues and all cell lines (Figure 2B and $2 \mathrm{~F}$ ).

We assessed the expression of p53 and Her2 in both original tumor tissues and cell lines. Tumor tissues from both patients exhibited Her2 expression (Figure 2C and 2G), however the level of expression was stronger in the TOV2223 tumor tissue (Figure 2G). This is concordant with Her2 expression in the cell lines by western blot analysis (Figure 2I). We also examined p53 expression by immunohistochemistry. Positive staining with the $p 53$ antigen is often indicative of TP53 gene mutation. The tissue from patient 1946 exhibited positive nuclear staining for $p 53$ (Figure 2D) in contrast to that observed with the tumor from the patient 2223 (Figure 2H). p53 positive immunoreactivity was mirrored in the cell lines by western blot (Figure 2I).

\section{Cell growth rate and tumorigenicity assays}

The growth characteristics of the new cell lines were also assessed (Table 2 and Figure 3 ) and compared to TOV$112 \mathrm{D}$, a cell line previously established and characterized in our laboratory [4]. The new EOC cell lines exhibited slower growth rates than the very aggressive TOV-112D reference cell line (Table 2 and Figure 3A). TOV-1946 has the shortest doubling time (1.3 days) when compared to the other two new cell lines (2.5 and 2.6 days for OV-1946 and TOV-2223 respectively). All cell lines exhibited similar saturation density although inferior (almost half) to that of TOV-112D. These results are consistent with the observation that TOV-112D exhibited small cells with a tendency to compact and form foci [4] as opposed to TOV-1946 and TOV-2223 cell lines which respectively show cells of medium and large size. The capacity of the new cell lines to form foci at high cell inocula and density 
A)

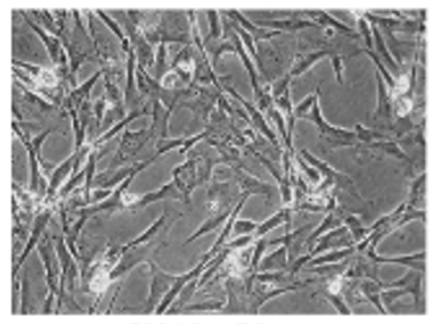

OV-1946 P0

())

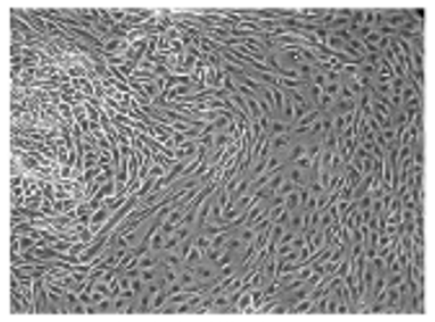

TOV-1946 P0

E)

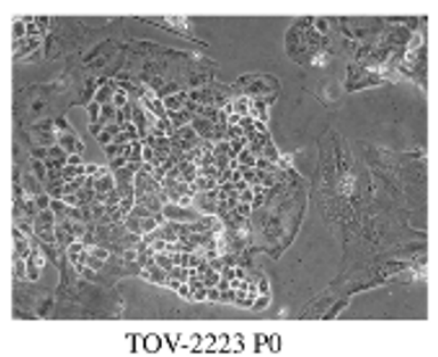

G)

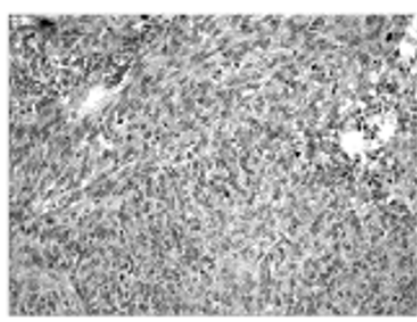

Tumor tissue 1946
B)

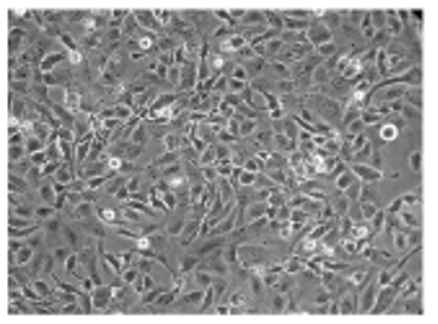

OV-1946 P70

D)

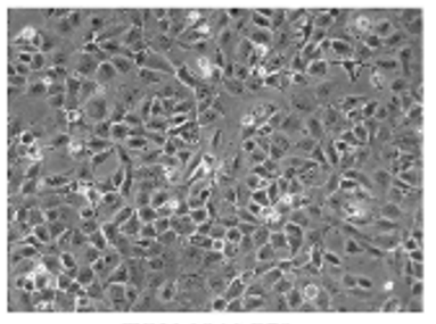

F)

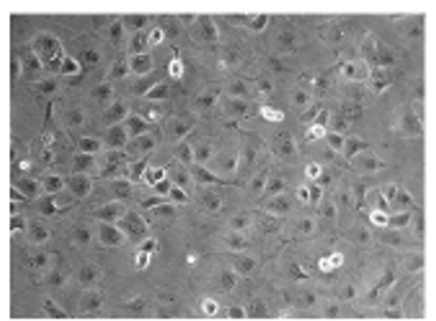

TOV-2223 P70

H)

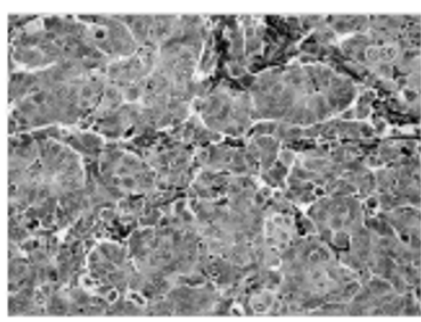

Tumor tissue 2223

\section{Figure I}

Cellular morphology of serous ovarian epithelium cancer cell lines and their corresponding tumoral tissues. A, C, E) Morphological appearance of the TOV-1946, OV-1946 and TOV-2223 cell lines respectively at passage 0. More (TOV1946 and TOV-2223) or less (OV-1946) heterogenous populations of cells with obvious fibroblastic contaminants are visible for all three cell lines. B,D,F) Appearance of TOV-1946, OV-I946 and TOV-2223 cell lines respectively at passage 70. An evolution toward a more homogenous population of cobblestone-like cells typical of an epithelial cell type. G,H) HematoxylinEosin stained tumor tissue sections of patient 1946 and 2223. Poorly differentiated tumor masses can be observed. All primary cultures and cell lines were cultured in OSE medium composed of 50:50 medium 199:105 (Sigma) supplemented with 10\% fetal bovine serum (FBS), $2.5 \mu \mathrm{g} / \mathrm{mL}$ amphotericin B and $50 \mu \mathrm{g} / \mathrm{mL}$ gentamicin. All photographs were taken at $400 \times$ magnification. 
A)

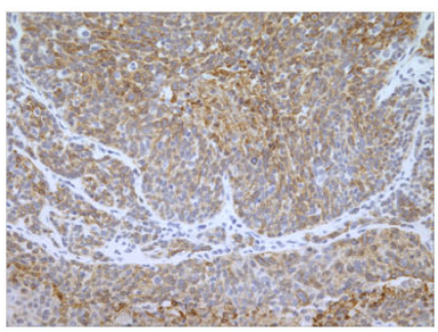

B)

Tumor tissue TOV-1946 Krt7

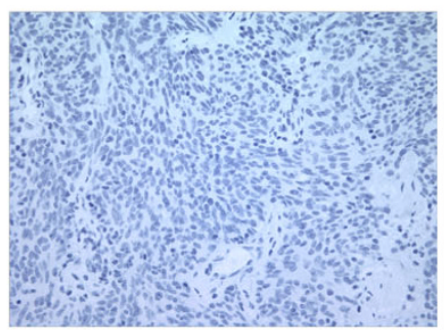

Tumor tissue TOV-1946 Krt20

C)

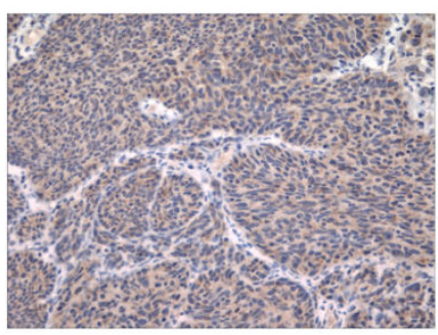

D)

Tumor tissue TOV-1946 Her2

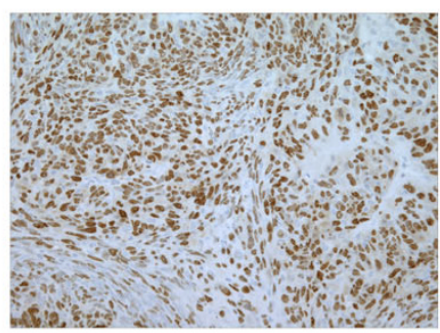

Tumor tissue TOV-1946 p53
E)

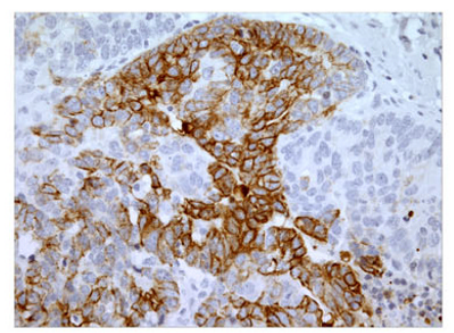

Tumor tissue TOV-2223 Krt7

F)

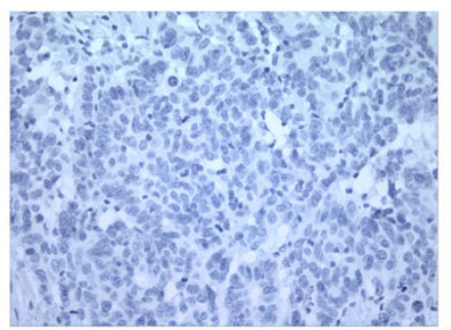

G)

H)

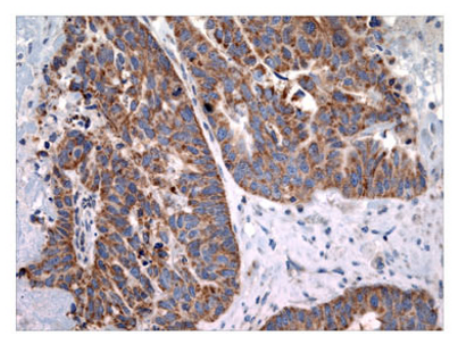

Tumor tissue TOV-2223 Her2

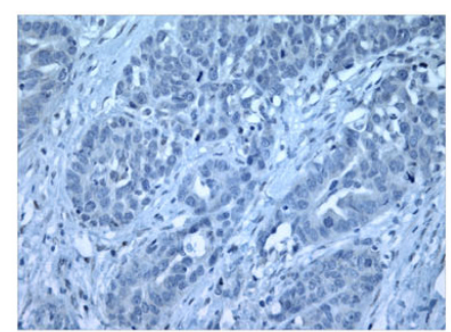

Tumor tissue TOV-2223 p53

I)

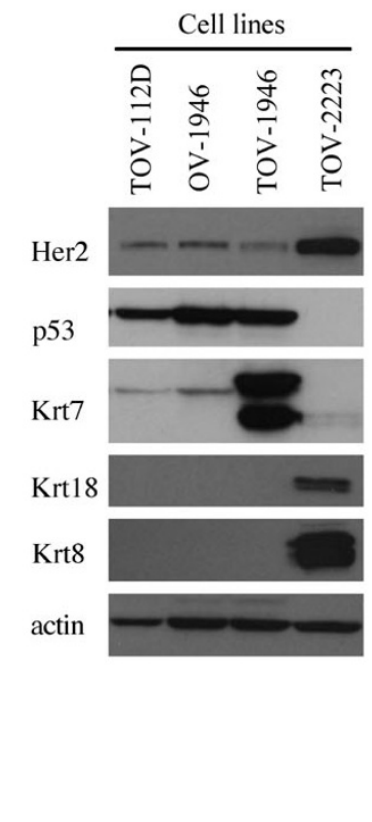


Table 2: Summary of cell line growth characteristics and tumorigenicity

\begin{tabular}{|c|c|c|c|c|c|}
\hline \multicolumn{2}{|c|}{ Cell line growth assays } & \multirow{2}{*}{$\begin{array}{c}\text { TOV-1946 } \\
1.3+/-0.4\end{array}$} & \multirow{2}{*}{$\begin{array}{l}\text { OV-1946 } \\
2.5+/-0.9\end{array}$} & \multirow{2}{*}{$\begin{array}{l}\text { TOV-2223 } \\
2.6+/-0.7\end{array}$} & \multirow{2}{*}{$\begin{array}{l}\text { TOV-II2D } \\
1.0+/-0.2\end{array}$} \\
\hline Growth & Doubling time (days) +/- S.D. ${ }^{a}$ & & & & \\
\hline & $\begin{array}{c}\text { Saturation density (nb cells }+/ \\
- \text { S.D.) }\end{array}$ & $\begin{array}{c}3053933+/-153 \\
933\end{array}$ & $\begin{array}{c}3231400+/-962 \\
723\end{array}$ & $\begin{array}{c}2536867+/-680 \\
852\end{array}$ & $6162133+/-515034$ \\
\hline & Number of passages to date & $>210$ & $>210$ & $>150$ & $>200$ \\
\hline Spheroid & Formation & aggregate & semi-compact & no & compact \\
\hline Migration & time for wound filling $(h)$ & 24 & 48 & $>48$ & 48 \\
\hline Invasion & $\begin{array}{c}\text { Mean number of cells }+/- \\
\text { S.D.c }\end{array}$ & $417+/-226$ & $149+/-70$ & $257+/-79$ & $118+/-34$ \\
\hline \multirow[t]{2}{*}{ Soft agarose } & Colony number +/- S.D.d & $11+/-3$ & $24+/-8$ & $16+/-4$ & $27+/-10$ \\
\hline & Colony size & large & large & small & large \\
\hline Low serum & $\begin{array}{l}\text { Capacity to grow in low } \\
\text { serum }(1 \%) \text { conditions }\end{array}$ & yes & yes & yes & yes \\
\hline \multirow{2}{*}{$\begin{array}{l}\text { Subcutaneous } \\
\text { injection in SCID } \\
\text { mice }\end{array}$} & $\begin{array}{l}\text { Number of mice with tumors } \\
\qquad(n=6)\end{array}$ & 0 & 0 & 0 & 5 \\
\hline & $\begin{array}{l}\text { Mean time of tumor } \\
\text { appearance (days) }\end{array}$ & N/A & N/A & N/A & 7 \\
\hline \multirow{3}{*}{$\begin{array}{l}\text { Intraperitoneal } \\
\text { injection in SCID } \\
\text { mice }\end{array}$} & $\begin{array}{l}\text { Number of mice with tumors } \\
\qquad(n=6)\end{array}$ & 3 & 5 & 0 & 6 \\
\hline & $\begin{array}{l}\text { Mean time of tumor } \\
\text { appearance (days) }\end{array}$ & 125 & 63 & N/A & 18 \\
\hline & Number of mice with ascitis & 2 & I & 0 & 2 \\
\hline
\end{tabular}

N/A not applicable

${ }^{a}$ calculated according to the slope of the linear portion of the growth curve.

brepresents the mean of maximum number of cells counted among the two independent experiments performed in triplicatat

cnumber of cells that migrate through the matrigel insert

${ }^{d}$ mean of colony numbers per representative area (minimum 5) from two independent experiment performed in duplicate

was also verified and confirmed. The cell lines described here exhibit all the qualities of an established immortalized cell lines as they were all kept in culture for more than 150 passages.

To further characterize the new cell lines, the migration potential was assessed (Table 2 and Figure 3B). TOV-1946 cells migrated faster than the other three cell lines, as they were able to close the wound in 24 hours. The migration patterns of TOV-112D and OV-1946 were similar and filled the wound in 48 hours. However, TOV-2223 migrated more slowly and needed more than 48 hours to close the wound.

Using the modified Boyden chambers, we then measured the capability of the cells to invade through matrigel membranes (Table 2 and Figure 3C). We noted an increase in invasion potential from TOV-112D, OV-1946, TOV-2223 and TOV-1946, where TOV-112D was the least invasive and TOV-1946 the most invasive.

We next monitored the capacity of the cells to form threedimensional structures in hanging droplets, a method routinely used in our laboratory. Only TOV-112D cells were able to form very compact spheroids, OV-1946 formed less compact spheroids, TOV-1946 cells formed loose aggregates of cells. The TOV-2223 cells were unable to form any aggregates and cells were individually spread across the droplet (Table 2 and Figure 3D).

We next measured the capability of the cell lines to grow in an anchorage independent environment by culturing the cells in soft agarose (Table 2). All cell lines were able to form colonies in soft agarose. The size of the colonies were similar for TOV-112D, TOV-1946 and OV-1946 but were larger than TOV-2223. The number of colonies increased from TOV-1946, TOV-2223, OV-1946 and TOV$112 \mathrm{D}$ with TOV-1946 having the lowest number of colonies and TOV112D the highest.

Finally, we monitored the potential of in vivo growth by injecting tumor cells at intraperitoneal or subcutaneous sites in SCID mice (Table 2). Subcutaneous tumors were observed only for the TOV-112D cell line. However, intraperitoneal (IP) tumors were also observed for the TOV1946 and OV1946 cell lines. The TOV-1946 cell line formed tumors in only 3 mice and only after an average of 125 days. The OV-1946 cell line formed tumors more rapidly (average 63 days) and a greater number of tumors (5 mice). The TOV2223 cell lines did not form tumors in 
A)

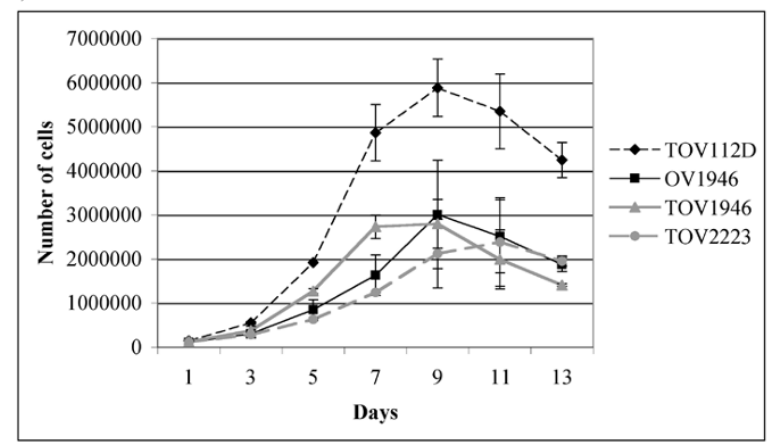

B)

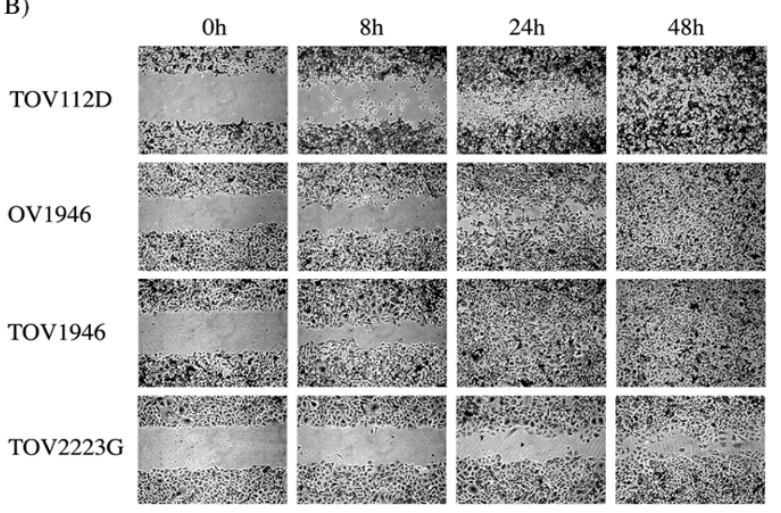

C)

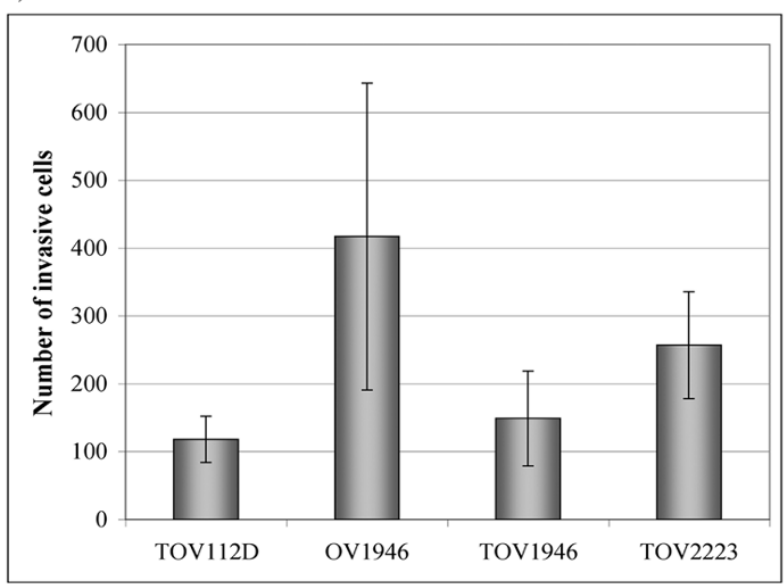

D)
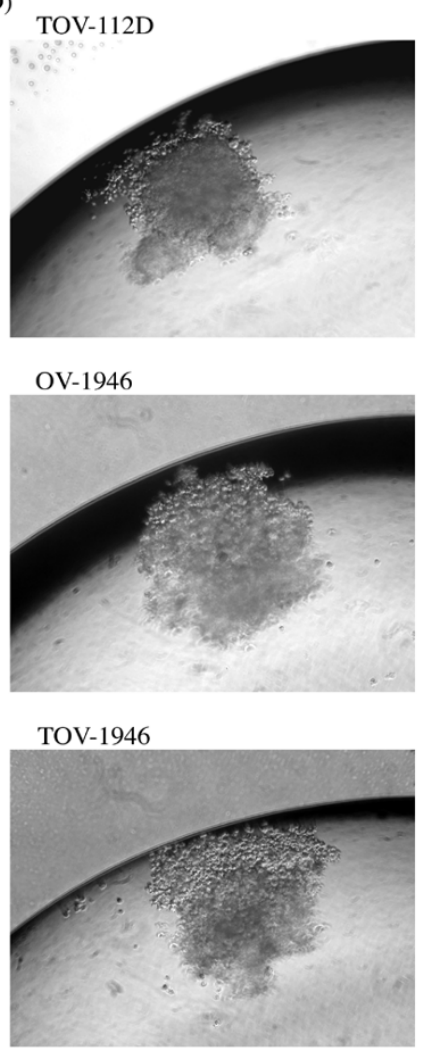

TOV-2223

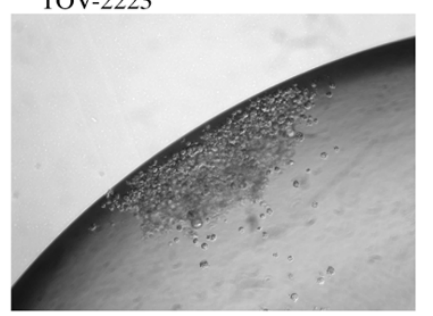

Figure 3

Cell growth rate and tumorigenicity assays. A) Growth curves of the three new cell lines as well as a previously characterized EOC TOV-II2D cell line. 100000 cells were plated onto $60 \mathrm{~mm}$ petri dishes. Cells were trypsinised and counted every $48 \mathrm{~h}$ for two weeks. Experiments were performed two times in triplicate. B) Wound-healing assay of the same four cell lines. Cells were plated onto a 12 well dish and at near confluence wounds were generated. Cells were methanol fixed and treated with Giemsa Stain at different time points in order to evaluate cell migration $(0 \mathrm{~h}, 8 \mathrm{~h}, 24 \mathrm{~h}$ and $48 \mathrm{~h}$ after the scratch was performed). The experiments were performed twice in triplicate. C) Invasion assay using modified Boyden chambers. The capability of the cells to invade through matrigel membranes was verified and the invasion potential increased from TOV-I I2D, OV-1946, TOV-2223 to TOV-1946. The experiments were performed in duplicate. D) The capacity of the cells to form threedimensional structures in hanging droplets was monitored. TOV-I I 2D cells were able to form very compact spheroids, OV1946 formed less compact spheroids, TOV-1946 cells formed loose aggregates of cells and TOV-2223 cells were unable to form any 3-D structure. Spheroid formation capability was visualized after four days. 
Table 3: Mutations status of the new EOC cell lines

\begin{tabular}{lcccc}
\hline Gene tested & TOVII2D & TOV-1946 & OV-I946 & TOV-2223G \\
\hline Somatic & & & & \\
\hline TP53 & EX5-36 G>A, RI75H & EX8+35 C>T, R273C & EX8+35 C>T, R273C & EX4+62 G>A, W53X \\
KRAS & - & - & - & - \\
BRAF & - & - & - & - \\
Microsatellite Instablility (MSI) & - & - & - \\
\hline Germline & - & & - \\
\hline BRCAI & - & - & - \\
BRCA2 & - & - & - \\
\hline
\end{tabular}

- = no mutations were found

mice (Table 2) however one mouse showed very small masses on liver lobes when all mice were sacrificed at approximately seven months post-injection (data not shown).

\section{Mutation status of the new EOC cell lines}

In order to further characterize the cell lines, we performed somatic mutation analysis of TP53, KRAS, and $B R A F$ as well as assayed for evidence of microsatellite instability (Table 3). Germline mutation (BRCA1 and $B R C A 2)$ analysis was limited to the recurrent mutations found in women of French-Canadian descent as cell lines were derived from patients of this ancestral origin [53]. Sequence variations in TP53 were identified in the DNA from all three EOC cell lines (Table 3). The same variant in exon 8, which is expected to confer an amino acid substitution of arginine to cysteine at codon 273, was identified in both TOV-1946 and OV-1946. The TP53 sequence variants are classified as deleterious mutations in the IARC TP53 mutation database $[57,58]$. The TP53 mutation status of TOV-1946 and OV-1946 is consistent with IHC results in these cell lines (Figure 2D and 2I). Although TOV-2223 harbors a TP53 mutation, IHC staining was negative (Figure 2). This is not inconsistent with independent reports that only a smaller fraction of cancers (about 12\%) harboring nonsense mutations exhibited IHC-positivity as compared to IHC-negative nonsense mutations (IARC TP53 mutation database) [57]. As TP53 mutation analysis revealed no evidence of heterozygosity, it is likely that no functional p53 is encoded in these cell lines. No mutations in the other genes studied were found in the cell lines.

\section{Cytogenetics and Spectral Karyotyping}

The cytogenetic alterations of the three cell lines were assessed by G-banded karyotyping and by spectral karyotyping (SKY). Twenty-five metaphases in G-banding and thirty-two metaphases in SKY (TOV-2223), twenty-two metaphases in G-banding and thirty-nine metaphases in
SKY (TOV-1946) and nineteen metaphases in G-banding and fifteen metaphases in SKY (OV-1946) were analyzed. The G-banded analysis of the three cell lines revealed a modal number of 51 to 71 chromosomes with complex karyotypes that are described as a composite karyotype containing the clonal chromosomal abnormalities (Table 4) $[55]$.

For the definition of the chromosomal breakpoints and the characterization of the marker chromosomes, the inverted-DAPI banding and spectral images were compared with the SKY-painted chromosomes of the same cell and then studied with the G-banded karyotypes for each cell line. This method allows a better identification of the numerous chromosomal rearrangements and several markers in each cell line. It is noteworthy that there were common but also unique chromosomal abnormalities when comparing the TOV-1946 and OV-1946 cell lines. Some representative metaphases are shown in Figures 4, 5 and 6 (see also Additional Files 1, 2, 3, 4, 5).

\section{Discussion}

In order to establish new cellular models of EOC, all samples of ovarian tissues collected for our tumor banks are processed to derive primary cell cultures. Occasionally, some of the primary cultures evolve to become immortal cell lines. So far, we have been successful in establishing seven EOC cell lines [4], three of which are described here. All cell lines were derived from patients who were never exposed to chemotherapy. This is of importance, since the majority of available cellular models originate from samples obtained following neoadjuvant therapy that could introduce genetic events not related to the biology of the disease.

Early in culture, cell lines presented heterogenous populations of cells that eventually progressed toward a more uniform population of cells with cobblestone-like morphology typical of epithelial cells. All cell lines grew as 
Table 4: G-banding composite karyotypes of the three ovarian cancer cell lines

\begin{tabular}{|c|c|}
\hline Cell line & G-banding composite karyotypes \\
\hline TOV-2223 & 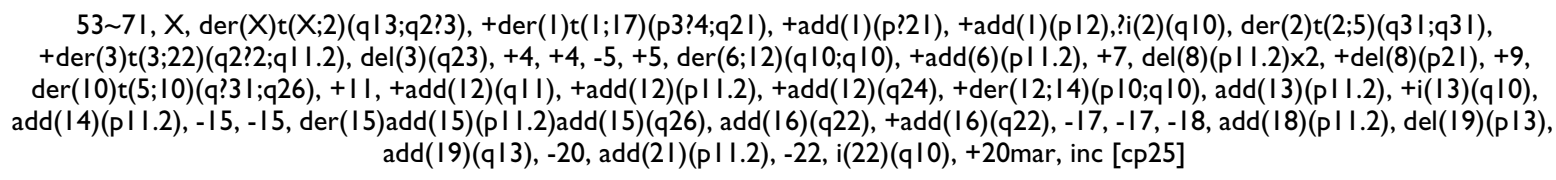 \\
\hline TOV-I946 & 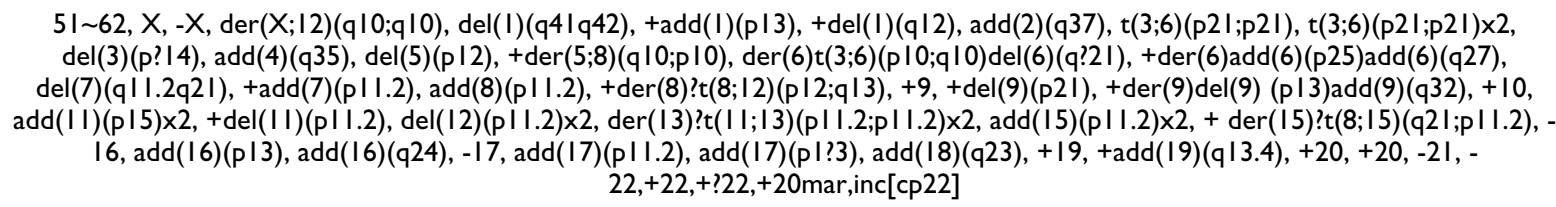 \\
\hline OV-1946 & 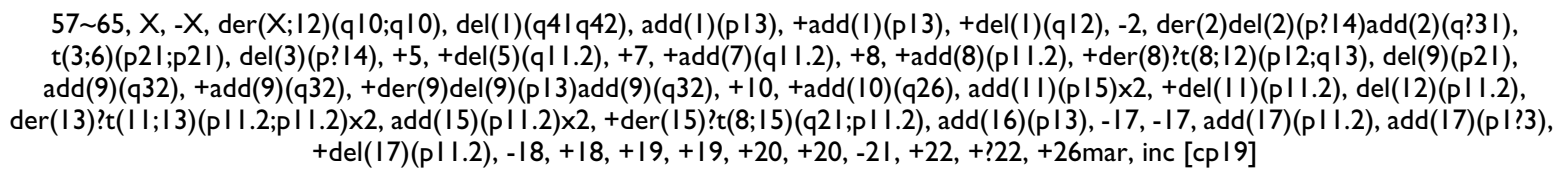 \\
\hline
\end{tabular}

adherent monolayers without evidence of cellular piling. However, we noted that TOV-2223 cells were more adherent to the petri dish when compared to TOV- and OV1946. Indeed, a longer trypsinization time is required to detach these cells from the petri dish. Also, when fixed in methanol, a large portion of both 1946 cell lines detached from the solid support while 2223 cells did not (data not shown). The homogeneity of cells observed at passage 0 of OV-1946 could reflect the fact that these cells came from a mass in the patient's ascites that is more homogenous then a tumor mass often composed of, among others, epithelial tumor cells, stromal cells and endothelial cells.

Cell lines were also evaluated on their capacity to survive and grow in low serum conditions. It is worth noticing that although in normal growth conditions both TOV and OV-1946 cell lines present similar growth rates, in low serum conditions the later is almost two times slower. This could be in line with the fact that the OV-1946 cell line comes from ascites which is rich in growth factors and in culture can replace FBS [59]. This cell line could hence be more dependent on growth signals provided by the environment as opposed to cells originating from solid tumors where cells may be predicted to be more self-sufficient.

In epithelial cells, intermediate filaments are composed of keratins that vary according to the differentiation of the cells. Both OSE and EOC tumors are characterized by the expression of different keratins such as KRT7, KRT8 and KRT18. In order to determine if our cell lines presented these EOC markers, we monitored protein expression of Krt7, Krt8 and Krt18 by western blot. When antibodies were appropriate for immunohistochemistry on paraffin embedded tissues, we also compared keratins expression in the original tumor tissues. It is also well described that monitoring expression of Krt7 and Krt20 could distinguish between ovarian and gastro-intestinal tract tumors (reviewed in [60]). Both the 1946 and the 2223 patients presented different epithelium specific Krt expression (Figure 2A and 2E) but did not express Krt20. It is worth noting that the Krt patterns were not all the same between different cell lines. Stronger expression of Krt7 is observed in TOV-1946 and TOV-2223G was the only cell line that expressed Krt18 and Krt8. This underlines the fact that these cell lines are biologically different even though they originate from tissues representing the same type of serous EOC disease. Moreover, Krt7 is also differentially expressed between the TOV-1946 and OV-1946 cell lines that not only originate from the same type of disease but also from the same patient and differences are related to solid tumor versus ascites.

In EOC, 25 to $30 \%$ of the tumors present an amplification of the HER2 gene leading to the overexpression of the protein Her2 (reviewed in [2,61-63]). The overexpression of this growth factor receptor alone was shown to be sufficient to induce malignant transformation and is implicated in ovarian cancer as well as many other types of cancer [64-67]. In EOCs of advanced stage, over 50\% of the tumors were shown to be mutated in the TP53 gene (reviewed in [2,61-63]). All three cell lines showed Her2 protein expression and contained TP53 gene mutations.

Differences in growth rates, migration, invasion and spheroid formation between the TOV-1946 and TOV-2223 underline the diversity of phenotypes that can be observed within the same type of serous EOC disease. The results from the comparison of the TOV-1946 and OV1946 growth characteristics, demonstrate that these cell 
A)

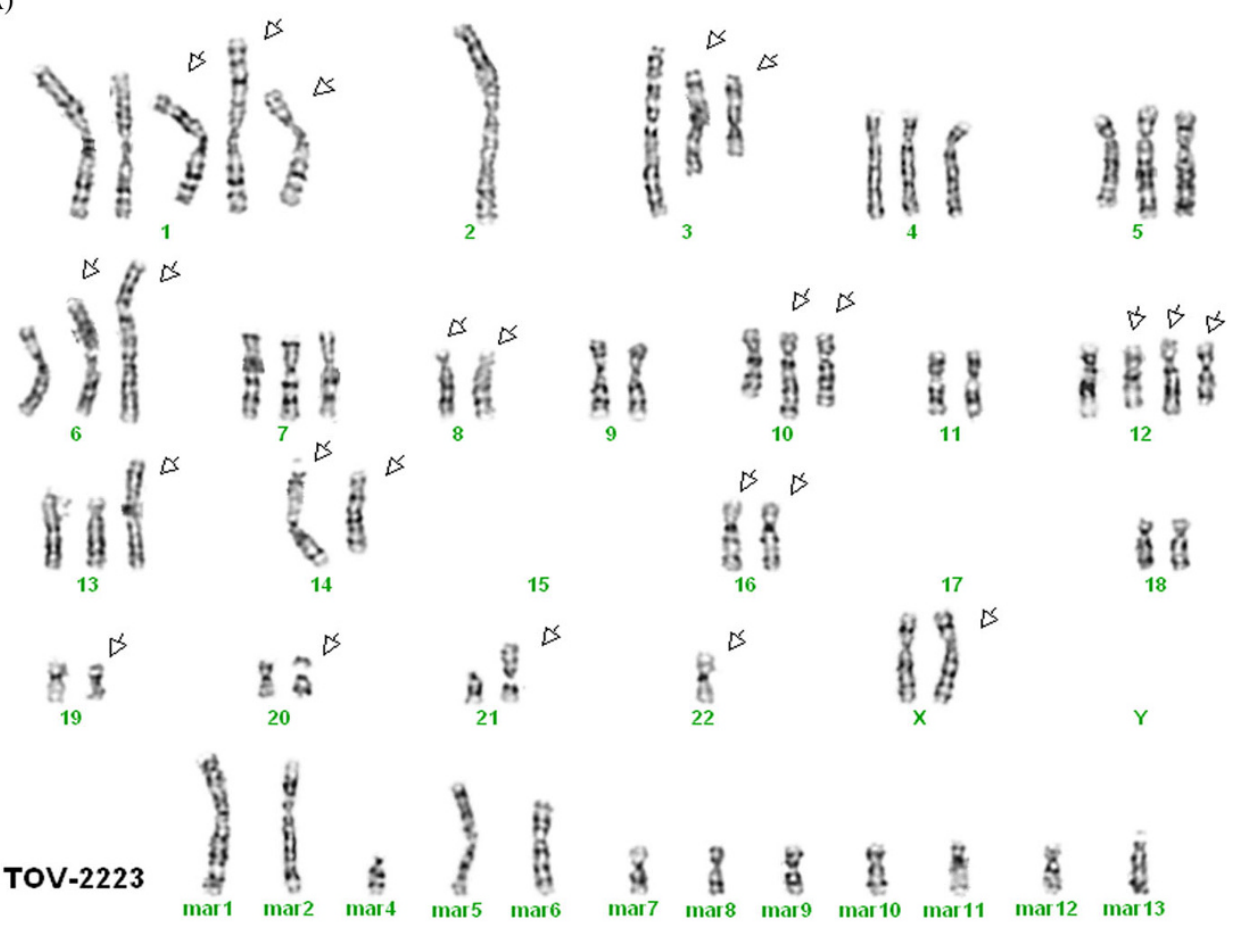

B)

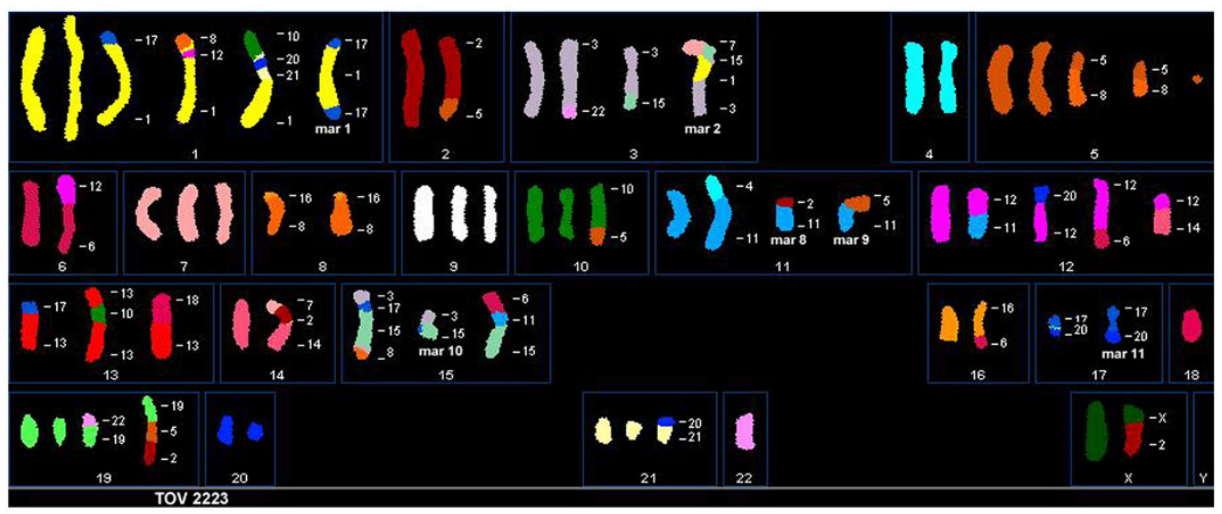

Figure 4

A) Representative G-banded metaphases from the TOV-2223 (cell I0) cell line. Arrows indicate the abnormal chromosomes, mar: marker chromosome. B) Representative metaphases from TOV-2223 (cell 45) analyzed by SKY. The origin of several marker chromosomes (mar) is defined by SKY analysis. Other examples of G-banded metaphases and the combined inverted-DAPI and SKY images of different cells are presented (see additional Files I and 2). 
A)

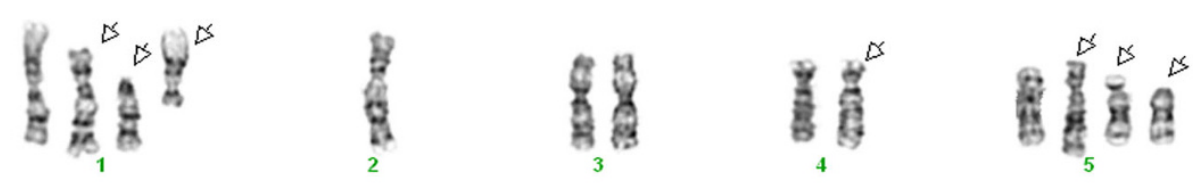

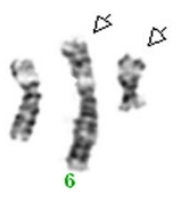
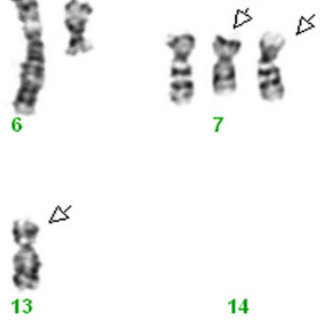

$\log _{19}^{\infty}$
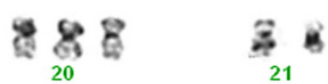

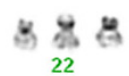
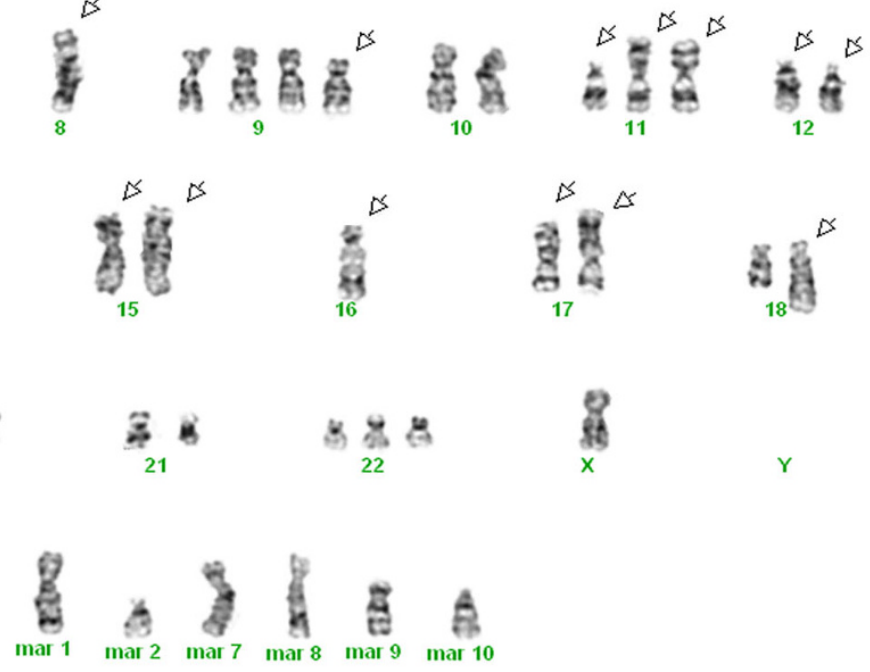

B)

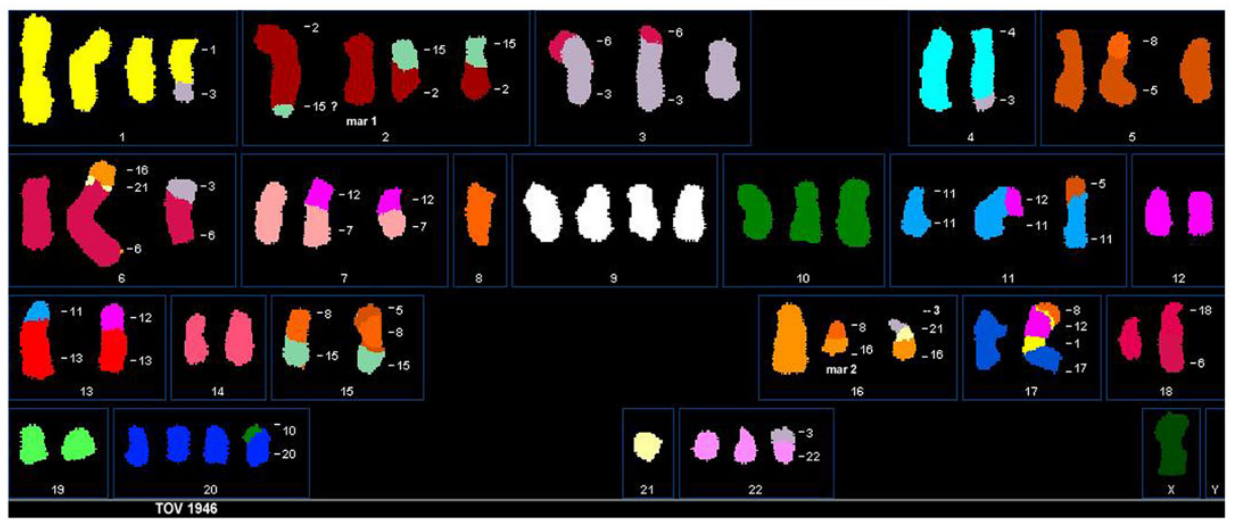

\section{Figure 5}

A) Representative G-banded metaphases from the TOV-1946 (cell 34) cell lines. Arrows indicate the abnormal chromosomes, mar: marker chromosome. B), D), F) Representative metaphases from TOV-1946 (cell 44) cell line analyzed by SKY. The origin of several marker chromosomes (mar) is defined by SKY analysis. Other examples of G-banded metaphases and the combined inverted-DAPI and SKY images of different cells are presented (see additional Files 3 and 4). 
A)
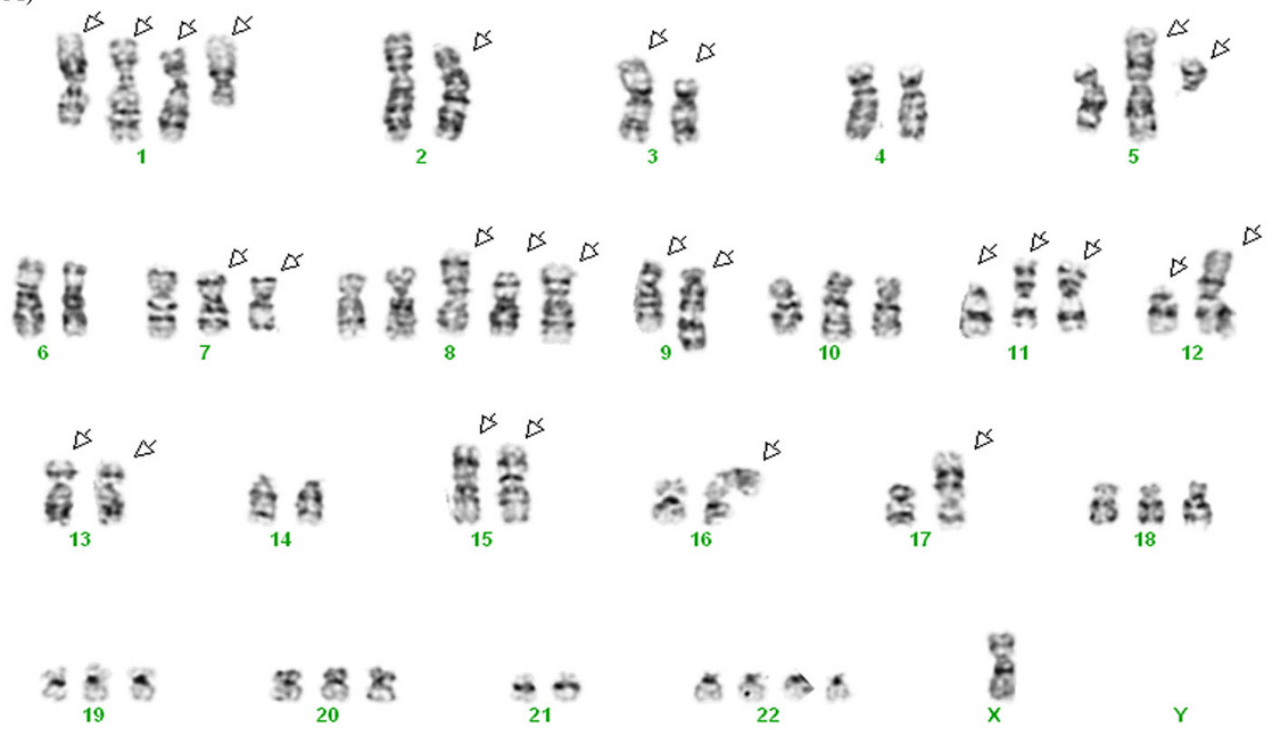

OV-1946

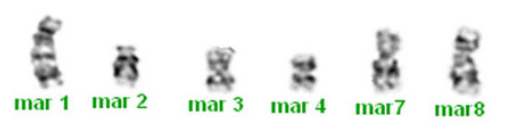

B)

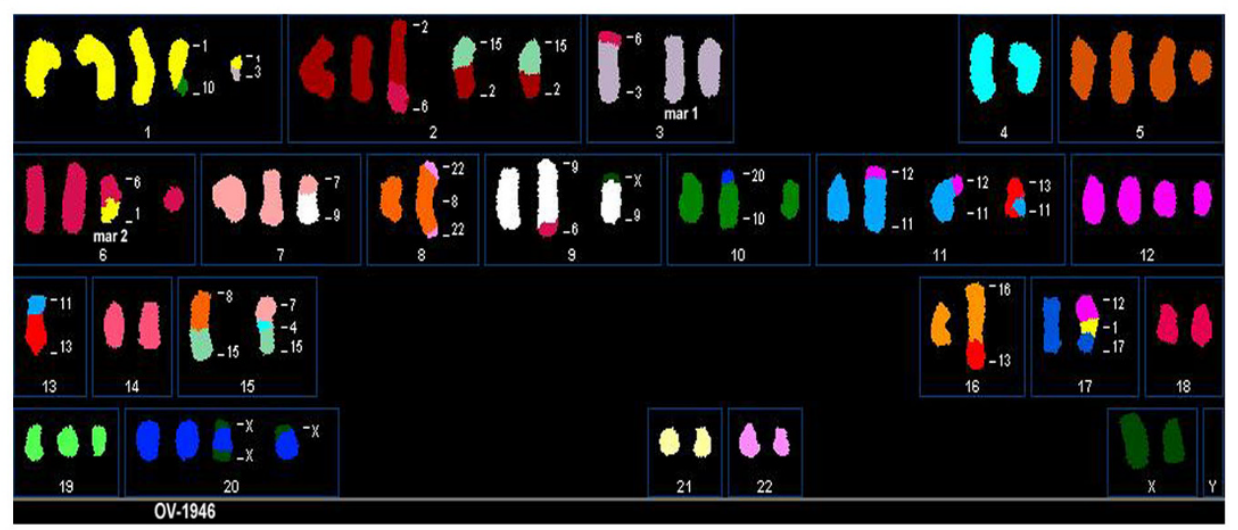

\section{Figure 6}

A) Representative G-banded metaphases from the OV-I 946 (cell I) cell line. Arrows indicate the abnormal chromosomes, mar: marker chromosome. B) Representative metaphases from OV-I946 (cell II) cell line analyzed by SKY. The origin of several marker chromosomes (mar) is defined by SKY analysis. Other examples of G-banded metaphases and the combined inverted-DAPI and SKY images of different cells are presented (see additional Files 5). 
lines present with unique phenotypes. Indeed, TOV-1946 cells had a better capability to invade and migrate although their capacity to form spheroid is reduced compared to the OV-1946 cells. One might speculate that cells derived from solid tumor conserve their migration and invasion property but in ascites, these characteristics are less vital. It has been previously shown that cells present in ascites form spheres or aggregates that can adhere to different extracellular matrices as well as to normal human mesothelial cells [68] but are not always invasive. The role of spheroids in ascites of ovarian cancer patients remains undefined. This is the first report of cell lines derived both from solid tumor and ascites cells of the same patient and further studies on these cell lines may provide useful insights into the biological progression of EOCs.

As both the TOV-1946 and OV-1946 injected mice developed ascites we hypothesize that the ability for cell lines to induce ascites formation in mice is intrinsic to the given cell line and independent of their origin (solid tumor versus ascites). It has been previously shown that the in vivo tumorigenicity can usually be predicted by the ability of the cells to grow in soft agar [69]. The OV-1946 cell line, which was the most tumorigenic, also formed the largest and most numerous colonies when seeded in soft agar (Table 2). In previous studies we have also observed that the capacity of the cells to form compact spheroids is related to their ability to form tumors in vivo [70]. Consistent with this notion, here we show that the OV-1946 cell line formed the most compact spheroids among the new cell lines and formed the greatest number of tumors with the shortest latency in xenograft experiments. However, the TOV-2223 cell line does not even form an aggregate in hanging droplets, only formed small colonies in soft agar and produced no tumors in SCID mice. The tumorigenicity results for TOV-2223 are also consistent with the relative indolent disease observed in patient 2223 who survived a relatively long period post diagnosis without treatment. Indeed, we have previously isolated the TOV81D cell lines, also from an indolent disease, which failed to form tumors in immuno-compromised mice [4] suggesting inherent qualities of the tumor that are reflected in its clinical behavior can affect this biological parameter.

The unique features of the described cell lines provide complementary models for different aspects of the disease. For example, while TOV-2223 and the TOV-1946 cell lines are both derived from solid tumors of the same type of serous EOC disease, they vary in important aspects including their aggressiveness and karyotype. They may prove useful for comparative studies to uncover molecular events that distinguish very aggressive from more indolent serous disease in ovarian cancer. Although the TOV-1946 and OV-1946 lines were derived from the same patient, they were collected from the solid tumor and the corresponding ascites respectively. Although common genome modification are shared between these two cell lines (see examples of modifications occurring on chromosome $\mathrm{X}$, $1,2,7,8,9,11,12,13,15$ and 16) (Table 4), others are unique either to the solid tumor or the ascites derived cell line (chromosome 2, 4, 5, 6, 7, 9, 16, 17, 18, 19, 20 and 22) (Table 4). These observations suggest that the two cell lines acquired common modifications during the earlier steps of tumorigenesis and during cancer progression different rearrangements were selected for, depending on the microenvironment.

The results obtained by SKY and G-banding assays reflect previously published karyotype studies on EOC where high genomic instability is observed [71]. Recently, it as been shown that recurrent rearrangements resulting in the formation of new fusion genes could be identified using genomic and bioinformatic tools [72-75]. So far such studies have been difficult to conduct on solid tumors and hence the importance of appropriate cellular models representing different types of tumors. The future fine cartography of recurrent lesions in these cell lines may provide insights into the molecular events that contribute to EOC initiation and progression.

\section{Conclusion}

In conclusion, this paper describes the establishment and characterization of three new serous EOC cell lines derived from two chemotherapy naïve patients. These cell lines are new and important tools in the study ovarian cancer disease, as few cell lines are described to date that represent this frequently diagnosed histopathology type of EOC. The rich characterization of these cell lines, including epithelial marker expression, growth characteristics, mutation and SKY analysis, provide the foundation for future experiments using these new models of EOC.

\section{Competing interests}

The authors declare that they have no competing interests.

\section{Authors' contributions}

$\mathrm{VO}$ and $\mathrm{MZ}$ performed the growth assays (growth rate, anchorage independent growth in soft agarose, threedimensional culture and growth in low serum), the wound-healing assays, mice assays as well as writing and editing of the manuscript according to all authors revisions. LP derived and established the new cell lines from tumor samples and performed the immunohistochemistry on the primary cultures and cell lines. JM performed the immunohistochemistry on tumor tissue. JL performed the Western blot.

M-LP performed the invasion assays. SLA and ZS performed mutations analyses. JH analyzed the SKY and G- 
banding assays. PNT, DMP and A-MM-M contributed to the conception and design of the study as well as analysis and interpretation of the data. All authors revised the manuscript and gave final verbal approval.

\section{Additional material}

\section{Additional file 1}

A) G-banded metaphases from the TOV-2223 cell line (cells 15 and 36 respectively). Arrows indicate the abnormal chromosomes, mar: marker chromosome. B) Combined inverted-DAPI and SKY image of cell 45 and 46 respectively from the TOV 2223 cell line with identification of some marker chromosomes.

Click here for file

[http://www.biomedcentral.com/content/supplementary/14712407-8-152-S1.tiff]

\section{Additional file 2}

A) G-banded metaphases from the TOV-2223 cell line (cells 15 and 36 respectively). Arrows indicate the abnormal chromosomes, mar: marker chromosome. B) Combined inverted-DAPI and SKY image of cell 45 and 46 respectively from the TOV 2223 cell line with identification of some marker chromosomes.

Click here for file

[http://www.biomedcentral.com/content/supplementary/14712407-8-152-S2.tiff]

\section{Additional file 3}

A) G-banded metaphases from the TOV-1946 cell line (cells 6 and 43 respectively). Arrows indicate the abnormal chromosomes, mar: marker chromosome. B) Combined inverted-DAPI and SKY image of cell 44 and 36 respectively from the TOV-1946 cell line with identification of some marker chromosomes.

Click here for file

[http://www.biomedcentral.com/content/supplementary/14712407-8-152-S3.tiff]

\section{Additional file 4}

A) G-banded metaphases from the TOV-1946 cell line (cells 6 and 43 respectively). Arrows indicate the abnormal chromosomes, mar: marker chromosome. B) Combined inverted-DAPI and SKY image of cell 44 and 36 respectively from the TOV-1946 cell line with identification of some marker chromosomes.

Click here for file

[http://www.biomedcentral.com/content/supplementary/1471-

2407-8-152-S4.tiff]

\section{Additional file 5}

A) G-banded metaphase from the OV-1946 cell line (cell 24). Arrows indicate the abnormal chromosomes, mar: marker chromosome. B) Combined inverted-DAPI and SKY image of cell 11 from the OV-1946 cell line with identification of some marker chromosomes.

Click here for file

[http://www.biomedcentral.com/content/supplementary/14712407-8-152-S5.tiff]

\section{Acknowledgements}

We are grateful to Véronique Barrès, Louise Champoux, Manon de Ladurantaye and Marise Roy for technical assistance. We thank Sylvie Lav- allée and Claude Rondeau (Leukemia Cell Bank of Quebec) for expert technical assistance in cytogenetics and spectral karyotyping. We would like to thank the Gynecologic Oncologist of CHUM for providing specimens. We are grateful to laboratory members for thoughtful discussion. This work was supported by a grant from the Cancer Research Society (CRS) to A.M.M.-M., P.N.T. and D.M.P. Tumor banking was supported by the Banque de tissus et de données of the Réseau de recherche sur le cancer of the Fonds de la recherche en santé du Québec (FRSQ), affiliated to the Canadian Tumor Repository Network (CTRNet). V.O. was supported by studentships from the Canadian Institute of Health Research (CIHR) and the Canderel Fund of the Institut du Cancer de Montréal. M.Z. was supported by studentship from the Marc Bourgie Fund of the Institut du Cancer de Montréal, the Canderel Fund of the Institut du Cancer de Montréal and the Faculté des études supérieures de l'Université de Montréal.

\section{References}

I. Colombo N, Van Gorp T, Parma G, Amant F, Gatta G, Sessa C, Vergote I: Ovarian cancer. Crit Rev Oncol Hematol 2006, 60:I59-I79.

2. Auersperg N, Wong AS, Choi KC, Kang SK, Leung PC: Ovarian surface epithelium: biology, endocrinology, and pathology. Endocr Rev 200I, 22:255-288.

3. Heintz AP, Odicino F, Maisonneuve P, Beller U, Benedet JL, Creasman WT, Ngan HY, Pecorelli S: Carcinoma of the ovary. Int J Gynaecol Obstet 2003, 83 Suppl I: I35-166.

4. Provencher DM, Lounis H, Champoux L, Tetrault M, Manderson EN, Wang JC, Eydoux P, Savoie R, Tonin PN, Mes-Masson AM: Characterization of four novel epithelial ovarian cancer cell lines. In Vitro Cell Dev Biol Anim 2000, 36:357-36I.

5. DiSaia PJ, Morrow M, Kanabus J, Piechal W, Townsend DE: Two new tissue culture lines from ovarian cancer. Gynecol Oncol 1975, 3:215-219.

6. Fogh J, Trempe G: New human tumor cell lines. In Human tumor cell lines in vitro Edited by: Fogh J. New York, Plenum Press; 1975.

7. Sinna GA, Beckman G, Lundgren E, Nordenson I, Roos G: Characterization of two human ovarian carcinoma cell lines. Gynecol Oncol 1979, 7:267-280.

8. Bast RC Jr., Feeney M, Lazarus H, Nadler LM, Colvin RB, Knapp RC: Reactivity of a monoclonal antibody with human ovarian carcinoma. J Clin Invest 1981, 68:1331-1337.

9. Hamilton TC, Young RC, McKoy WM, Grotzinger KR, Green JA, Chu EW, Whang-Peng J, Rogan AM, Green WR, Ozols RF: Characterization of a human ovarian carcinoma cell line (NIH:OVCAR3) with androgen and estrogen receptors. Cancer Res 1983, 43:5379-5389.

10. Buick RN, Pullano R, Trent JM: Comparative properties of five human ovarian adenocarcinoma cell lines. Cancer Res 1985 , 45:3668-3676.

II. Hill BT, Whelan RD, Gibby EM, Sheer D, Hosking LK, Shellard SA, Rupniak HT: Establishment and characterisation of three new human ovarian carcinoma cell lines and initial evaluation of their potential in experimental chemotherapy studies. Int J Cancer 1987, 39:219-225.

12. Langdon SP, Lawrie SS, Hay FG, Hawkes MM, McDonald A, Hayward IP, Schol DJ, Hilgers J, Leonard RC, Smyth JF: Characterization and properties of nine human ovarian adenocarcinoma cell lines. Cancer Res 1988, 48:6166-6172.

13. Briers TW, Stroobants P, Vandeputte TM, Nouwen EJ, Conraads MV, Eestermans G, Van Bockstaele D, De Broe ME: Establishment and characterization of a human ovarian neoplastic cell line, DOs. Cancer Res 1989, 49:5153-516I.

14. Golombick T, Dansey R, Bezwoda WR, Rosendorff J: Establishment and characterization of two new human ovarian cancer cell lines UWOVI and UWOV2 and a subline UWOV2 (Sf) growing in serum-free conditions: growth characteristics, biochemical, and cytogenetic studies. In Vitro Cell Dev Biol 1990, 26:447-454

15. Wong WS, Wong YF, Ng YT, Huang PD, Chew EC, Ho TH, Chang $M Z$ : Establishment and characterization of a new human cell line derived from ovarian clear cell carcinoma. Gynecol Oncol 1990, 38:37-45.

16. Golombick T, Bezwoda WR: In vitro maintenance of a new ovarian cancer cell line in protein-free media: a potential model 
for autonomous growth and tumor progression. Eur J Cell Biol I991, 56:459-463.

17. Yamada T, Ueda M, Otsuki Y, Ueki M, Sugimoto O: Establishment and characterization of a cell line (OMC-3) originating from a human mucinous cystadenocarcinoma of the ovary. Gynecol Oncol 1991, 40:118-128.

18. Mobus V, Gerharz CD, Press U, Moll R, Beck T, Mellin W, Pollow K, Knapstein PG, Kreienberg R: Morphological, immunohistochemical and biochemical characterization of 6 newly established human ovarian carcinoma cell lines. Int J Cancer 1992, 52:76-84.

19. Grunt TW, Oeller H, Somay C, Dittrich C: Different propensity for spontaneous differentiation of cell clones isolated from the human ovarian surface epithelial cell line HOC-7. Differentiation 1993, 53:45-50.

20. Provencher DM, Finstad CL, Saigo PE, Rubin SC, Hoskins WJ, Federici MG, Stockert E, Lloyd KO, Lewis JL Jr.: Comparison of antigen expression on fresh and cultured ascites cells and on solid tumors of patients with epithelial ovarian cancer. Gynecol Oncol 1993, 50:78-83.

21. Hirte HW, Kaiser JS, Bacchetti S: Establishment and characterization of four human epithelial ovarian carcinoma cell lines. Cancer 1994, 74:900-906.

22. Buller RE, Niemann T, Connor JP, Squatrito RC, Skilling JS, Anderson $B$ : Isolation and preliminary characterization of an ovarian carcinoma cell line from a patient with familial ovarian cancer. Gynecol Oncol 1995, 56:39-44.

23. Alama A, Barbieri F, Favre A, Cagnoli M, Noviello E, Pedulla F, Viale M, Foglia G, Ragni N: Establishment and characterization of three new cell lines derived from the ascites of human ovarian carcinomas. Gynecol Oncol 1996, 62:82-88

24. Kim JW, Lee CG, Lyu MS, Kim HK, Rha JG, Kim DH, Kim SJ, Namkoong SE: A new cell line from human undifferentiated carcinoma of the ovary: establishment and characterization. Cancer Res Clin Oncol 1997, I 23:82-90.

25. Mancini A, Borrelli A, Formisano S, Masucci MT, Maffeo A, Perla G, De Martino L, Bevilacqua N, Botti G, Maggino T: Establishment and growth regulation of a novel ovarian cancer cell line from a poorly-differentiated adenocarcinoma: proposal for a new treatment. Eur J Gynaecol Oncol 1999, 20:45-52.

26. Bar JK, Harlozinska A: Morphological and phenotypic characterization of a new established ovarian carcinoma cell line (OvBH-I). Anticancer Res 2000, 20:2975-2980.

27. Sato S, Kobayashi Y, Okuma Y, Kondo H, Kanishi Y, Saito K, Kiguchi $\mathrm{K}$ : Establishment and characterization of a cell-line originated from human mucinous cystadenocarcinoma of the ovary. Hum Cell 2002, I5: I71-177.

28. Saga Y, Suzuki M, Machida S, Ohwada M, Sato I: Establishment of a new cell line (TAYA) of clear cell adenocarcinoma of the ovary and its radiosensitivity. Oncology 2002, 62:180-I84.

29. Nishikawa Y, Yoshida Y, Kawahara K, Kurokawa T, Tajima K, Kotsuji $F$ : Establishment of a novel human ovarian cancer cell line with high anchorage-independent growth ability. Int J Oncol 2003, 23: I679-I686.

30. Woods LK, Morgan RT, Quinn LA, Moore GE, Semple TU, Stedman $\mathrm{KE}$ : Comparison of four new cell lines from patients with adenocarcinoma of the ovary. Cancer Res 1979, 39:4449-4459.

31. Crickard K, Niedbala MJ, Crickard U, Yoonessi M, Sandberg AA, Okuyama K, Bernacki RJ, Satchidanand SK: Characterization of human ovarian and endometrial carcinoma cell lines established on extracellular matrix. Gynecol Oncol 1989, 32:163-173.

32. Imai S, Kiyozuka Y, Maeda H, Noda T, Hosick HL: Establishment and characterization of a human ovarian serous cystadenocarcinoma cell line that produces the tumor markers CAI 25 and tissue polypeptide antigen. Oncology 1990, 47: I77-184.

33. van den Berg-Bakker CA, Hagemeijer A, Franken-Postma EM, Smit VT, Kuppen PJ, van Ravenswaay Claasen HH, Cornelisse Cl, Schrier $\mathrm{PI}$ : Establishment and characterization of 7 ovarian carcinoma cell lines and one granulosa tumor cell line: growth features and cytogenetics. Int I Cancer 1993, 53:6 |3-620.

34. Yonamine K, Hayashi K, lida T: Establishment and characterization of human ovarian clear cell adenocarcinoma cell line (SMOV-2), and its cytotoxity by anticancer agents. Hum Cell 1999, I2:139-148.

35. Emoto M, Oshima K, Ishiguro M, Iwasaki H, Kawarabayashi T, Kikuchi $M$ : Establishment and characterization of a serous papillary adenocarcinoma cell line of the human ovary in a serum-free culture. Pathol Res Pract 1999, 195:237-242.

36. Aoki D, Suzuki N, Susumu N, Noda T, Suzuki A, Tamada Y, Higashiguchi A, Oie S, Nozawa S: Establishment and characterization of the RMG-V cell line from human ovarian clear cell adenocarcinoma. Hum Cell 2005, I 8:|43-| 46.

37. Scoles DR, Pavelka J, Cass I, Tran H, Baldwin RL, Armstrong K, Karlan BY: Characterization of CSOC 882, a novel immortalized ovarian cancer cell line expressing EGFR, HER2, and activated AKT. Gynecol Oncol 2007, 104: | 20-128.

38. Auersperg N, Maines-Bandiera SL, Dyck HG, Kruk PA: Characterization of cultured human ovarian surface epithelial cells: phenotypic plasticity and premalignant changes. Lab Invest 1994, 71:510-518.

39. Nitta $\mathrm{M}$, Katabuchi $\mathrm{H}$, Ohtake $\mathrm{H}$, Tashiro $\mathrm{H}$, Yamaizumi M, Okamura $\mathrm{H}$ : Characterization and tumorigenicity of human ovarian surface epithelial cells immortalized by SV40 large T antigen. Gynecol Oncol 200I, 8I: I0-I7.

40. Shenhua X, Lijuan Q, Hanzhou N, Xinghao N, Chihong Z, Gu Z, Weifang D, Yongliang G: Establishment of a highly metastatic human ovarian cancer cell line (HO-89 I OPM) and its characterization. J Exp Clin Cancer Res 1999, 18:233-239.

4I. Yabushita H, Ueno N, Sawaguchi K, Higuchi K, Noguchi M, Ishihara $M$ : Establishment and characterization of a new human cellline (AMOC-2) derived from a serous adenocarcinoma of ovary. Nippon Sanka Fujinka Gakkai Zasshi 1989, 41:888-894.

42. Kruk PA, Maines-Bandiera SL, Auersperg N: A simplified method to culture human ovarian surface epithelium. Lab Invest 1990 63: 132-136.

43. Lounis H, Provencher D, Godbout C, Fink D, Milot MJ, Mes-Masson AM: Primary cultures of normal and tumoral human ovarian epithelium: a powerful tool for basic molecular studies. Exp Cell Res 1994, 2 1 5:303-309.

44. Keller GM: In vitro differentiation of embryonic stem cells. Curr Opin Cell Biol 1995, 7:862-869.

45. Zietarska M, Maugard CM, Filali-Mouhim A, Alam-Fahmy M, Tonin PN, Provencher D, Mes-Masson AM: Molecular description of a 3-D in vitro model for the study of epithelial ovarian cancer. Mol Carcinog 2007, In Press:

46. Bossolasco M, Veillette F, Bertrand R, Mes-Masson AM: Human TDEI, a TDEI/TMS family member, inhibits apoptosis in vitro and stimulates in vivo tumorigenesis. Oncogene 2006 , 25:4549-4558.

47. Shigeta M, Sanzen N, Ozawa M, Gu J, Hasegawa H, Sekiguchi K: CDI5I regulates epithelial cell-cell adhesion through PKCand Cdc42-dependent actin cytoskeletal reorganization. J Cell Biol 2003, I 63:165-176.

48. Ronot X, Doisy A, Tracqui P: Quantitative study of dynamic behavior of cell monolayers during in vitro wound healing by optical flow analysis. Cytometry 2000, 4I:19-30.

49. Arcand SL, Provencher D, Mes-Masson AM, Tonin PN: OGG I Cys326 variant, allelic imbalance of chromosome band 3 p25.3 and TP53 mutations in ovarian cancer. Int J Oncol 2005, 27:1315-1320.

50. Arcand SL, Maugard CM, Ghadirian P, Robidoux A, Perret C, Zhang P, Fafard E, Mes-Masson AM, Foulkes WD, Provencher D, Narod SA Tonin PN: Germline TP53 mutations in BRCAI and BRCA2 mutation-negative French Canadian breast cancer families. Breast Cancer Res Treat 2007.

5I. Samouelian V, Maugard CM, Jolicoeur M, Bertrand R, Arcand SL, Tonin PN, Provencher DM, Mes-Masson AM: Chemosensitivity and radiosensitivity profiles of four new human epithelial ovarian cancer cell lines exhibiting genetic alterations in BRCA2, TGFbeta-RII, KRAS2, TP53 and/or CDNK2A. Cancer Chemother Pharmacol 2004, 54:497-504.

52. Davies H, Bignell GR, Cox C, Stephens P, Edkins S, Clegg S, Teague J, Woffendin H, Garnett MJ, Bottomley W, Davis N, Dicks E, Ewing R, Floyd Y, Gray K, Hall S, Hawes R, Hughes J, Kosmidou V, Menzies A, Mould C, Parker A, Stevens C, Watt S, Hooper S, Wilson R, Jayatilake H, Gusterson BA, Cooper C, Shipley J, Hargrave D, Pritchard-Jones K, Maitland N, Chenevix-Trench G, Riggins GJ, Bigner DD, Palmieri G, Cossu A, Flanagan A, Nicholson A, Ho JW, Leung SY, Yuen ST, Weber BL, Seigler HF, Darrow TL, Paterson H, Marais R, Marshall C], Wooster R, Stratton MR, Futreal PA: Mutations of the BRAF gene in human cancer. Nature 2002, 41 7:949-954. 
53. Oros KK, Ghadirian P, Greenwood CM, Perret C, Shen Z, Paredes $Y$, Arcand SL, Mes-Masson AM, Narod SA, Foulkes WD, Provencher D, Tonin PN: Significant proportion of breast and/or ovarian cancer families of French Canadian descent harbor I of 5 BRCA I and BRCA2 mutations. Int J Cancer 2004, | | 2:4 | | -4 | 9.

54. Tonin PN, Mes-Masson AM, Futreal PA, Morgan K, Mahon M, Foulkes WD, Cole DE, Provencher D, Ghadirian P, Narod SA: Founder BRCAI and BRCA2 mutations in French Canadian breast and ovarian cancer families. Am J Hum Genet 1998, 63: $|34|-|35|$.

55. Shaffer LG, Tommerup N: ISCN, An International System for Human Cytogenetic Nomenclature. Basel, S. Karger AG; 2005.

56. Applied Spectral Imaging (ASI) [http://www.spectral-imag ing.com/]

57. Petitjean A, Mathe E, Kato S, Ishioka C, Tavtigian SV, Hainaut $P$, Olivier M: Impact of mutant p53 functional properties on TP53 mutation patterns and tumor phenotype: lessons from recent developments in the IARC TP53 database. Hum Mutat 2007, 28:622-629.

58. IARC TP53 mutation database [http://www-p53.iarc.fr/]

59. Puiffe ML, Le Page C, Filali-Mouhim A, Zietarska M, Ouellet V, Tonin PN, Chevrette M, Provencher DM, Mes-Masson AM: Characterization of ovarian cancer ascites on cell invasion, proliferation, spheroid formation, and gene expression in an in vitro model of epithelial ovarian cancer. Neoplasia 2007, 9:820-829.

60. Prat J: Ovarian carcinomas, including secondary tumors: diagnostically challenging areas. Mod Pathol 2005, 18 Suppl 2:S99-III.

61. Boente MP, Hurteau J, Rodriguez GC, Bast RC Jr., Berchuck A: The biology of ovarian cancer. Curr Opin Oncol 1993, 5:900-907.

62. Berchuck A, Elbendary A, Havrilesky L, Rodriguez GC, Bast RC Jr.: Pathogenesis of ovarian cancers. J Soc Gynecol Investig 1994, I: $181-190$

63. Aunoble B, Sanches R, Didier E, Bignon YJ: Major oncogenes and tumor suppressor genes involved in epithelial ovarian cancer (review). Int J Oncol 2000, 16:567-576.

64. Meden H, Kuhn W: Overexpression of the oncogene c-erbB-2 (HER2/neu) in ovarian cancer: a new prognostic factor. [Review] [36 refs]. Eur J Obstet Gynecol Rep Biol I997, 7 I: I73-I79.

65. Meden H, Marx D, Schauer A, Wuttke W, Kuhn W: Prognostic sig. nificance of pl05 (c-erbB-2 HER2/neu) serum levels in patients with ovarian cancer. Anticancer Res 1997, 17:757-760.

66. Slamon DJ, Clark GM, Wong SG, Levin WJ, Ullrich A, McGuire WL: Human breast cancer: correlation of relapse and survival with amplification of the HER-2/neu oncogene. Science 1987 235: $177-182$.

67. Calvo BF, Levine AM, Marcos M, Collins QF, lacocca MV, Caskey LS, Gregory CW, Lin Y, Whang YE, Earp HS, Mohler JL: Human epidermal receptor-2 expression in prostate cancer. Clin Cancer Res 2003, 9:1087-1097.

68. Burleson KM, Boente MP, Pambuccian SE, Skubitz AP: Disaggregation and invasion of ovarian carcinoma ascites spheroids. J Transl Med 2006, 4:6.

69. Freedman VH, Shin Sl: Cellular tumorigenicity in nude mice: correlation with cell growth in semi-solid medium. Cell 1974 3:355-359.

70. Cody NA, Ouellet V, Manderson EN, Quinn MC, Filali-Mouhim A, Tellis P, Zietarska M, Provencher DM, Mes-Masson AM, Chevrette M, Tonin PN: Transfer of chromosome 3 fragments suppresses tumorigenicity of an ovarian cancer cell line monoallelic for chromosome 3p. Oncogene 2007, 26:6|8-632.

7I. Taetle R, Aickin M, Yang JM, Panda L, Emerson J, Roe D, Adair L Thompson F, Liu Y, Wisner L, Davis JR, Trent J, Alberts DS: Chromosome abnormalities in ovarian adenocarcinoma: I. Nonrandom chromosome abnormalities from 244 cases. Genes Chromosomes Cancer 1999, 25:290-300.

72. Tomlins SA, Laxman B, Dhanasekaran SM, Helgeson BE, Cao X, Morris DS, Menon A, Jing X, Cao Q, Han B, Yu J, Wang L, Montie JE, Rubin MA, Pienta KJ, Roulston D, Shah RB, Varambally S, Mehra R, Chinnaiyan AM: Distinct classes of chromosomal rearrangements create oncogenic ETS gene fusions in prostate cancer. Nature 2007, 448:595-599.

73. Tomlins SA, Rhodes DR, Perner S, Dhanasekaran SM, Mehra R, Sun $X W$, Varambally S, Cao X, Tchinda J, Kuefer R, Lee C, Montie JE, Shah RB, Pienta KJ, Rubin MA, Chinnaiyan AM: Recurrent fusion of
TMPRSS2 and ETS transcription factor genes in prostate cancer. Science 2005, 3 1 0:644-648.

74. Martin ES, Tonon G, Sinha R, Xiao Y, Feng B, Kimmelman AC, Protopopov A, Ivanova E, Brennan C, Montgomery K, Kucherlapati R, Bailey G, Redston M, Chin L, DePinho RA: Common and distinct genomic events in sporadic colorectal cancer and diverse cancer types. Cancer Res 2007, 67:10736-10743.

75. Weir BA, Woo MS, Getz G, Perner S, Ding L, Beroukhim R, Lin WM, Province MA, Kraja A, Johnson LA, Shah K, Sato M, Thomas RK, Barletta JA, Borecki IB, Broderick S, Chang AC, Chiang DY, Chirieac LR, Cho J, Fujii Y, Gazdar AF, Giordano T, Greulich H, Hanna M, Johnson $B E$, Kris MG, Lash A, Lin L, Lindeman N, Mardis ER, McPherson JD, Minna JD, Morgan MB, Nadel M, Orringer MB, Osborne JR, Ozenberger B, Ramos AH, Robinson J, Roth JA, Rusch V, Sasaki H, Shepherd F, Sougnez C, Spitz MR, Tsao MS, Twomey D, Verhaak RG, Weinstock GM, Wheeler DA, Winckler W, Yoshizawa A, Yu S, Zakowski MF, Zhang Q, Beer DG, Wistuba, Watson MA, Garraway LA, Ladanyi M, Travis WD, Pao W, Rubin MA, Gabriel SB, Gibbs RA, Varmus HE, Wilson RK, Lander ES, Meyerson M: Characterizing the cancer genome in lung adenocarcinoma. Nature 2007.

\section{Pre-publication history}

The pre-publication history for this paper can be accessed here:

http://www.biomedcentral.com/1471-2407/8/152/pre pub

Publish with Bio Med Central and every scientist can read your work free of charge

"BioMed Central will be the most significant development for disseminating the results of biomedical research in our lifetime. "

Sir Paul Nurse, Cancer Research UK

Your research papers will be:

- available free of charge to the entire biomedical community

- peer reviewed and published immediately upon acceptance

- cited in PubMed and archived on PubMed Central

- yours - you keep the copyright 